\title{
Democracy vs. Populism: the transformation of politics in Nigeria?
}

\author{
Ibikunle Adeakin ${ }^{1}$ e Daniel Zirker ${ }^{2}$ \\ $1 \mathrm{PhD}$. Lecturer, Department of History and International Studies, Ajayi Crowther University. Oyo, Nigeria. Email: \\ ibkforever_007@yahoo.com \\ 2 Professor of Political Science University of Waikato. Hamilton, New Zealand. Email: daniel.zirker@waikato.ac.nz
}

\begin{abstract}
Since the return of electoral democracy to Nigeria in 1999, two of the four elected presidents have been former military dictators who have stressed anticorruption and national security policies in populist campaigns. As military dictators in previous years, they had instigated regimes that had practiced stern military discipline; as populists they have leaned toward these two policies. Reactions to civilian corruption and threats to national security have represented the primary military rationales for military intervention in the past. A popular vote in 2015 for former military dictator General Muhammadu Buhari seems to have represented a continuing preference for populism over democracy. We will examine the new populism in Nigeria, complicated as it is by questions of ethnicity, religion and military identity, with a view to explaining the likely outcome of the first peaceful transference of power from one political party to another in Africa's most populous country.
\end{abstract}

Keywords: neo-liberal military-directed populism; democracy; democratization; corruption; national security.

\section{Democracia vs. Populismo: A Transformação da Política na Nigéria?}

RESUMO: Desde o retorno da democracia eleitoral à Nigéria em 1999, dois dos quatro presidentes eleitos foram ex-ditadores militares que enfatizaram as políticas anticorrupção e de segurança nacional em campanhas populistas. Como ditadores militares nos anos anteriores, instigaram regimes que haviam praticado severa disciplina militar; como populistas se inclinaram para estas duas políticas. As reações à corrupção civil e às ameaças à segurança nacional representaram as principais razões militares para a intervenção militar no passado. Um voto popular em 2015 para o ex-ditador militar Muhammadu Buhari parece ter representado uma preferência contínua pelo populismo sobre a democracia. Examinaremos o novo populismo na Nigéria, complicado por questões de etnicidade, religião e identidade militar, a fim de explicar o provável resultado da primeira transferência pacífica de poder de um partido político para outro no país mais populoso de África.

Palavras-chave: populismo; neo-liberal, democracia; democratização; corrupção; segurança nacional

"The trouble with Nigeria is simply and squarely a failure of leadership." Chinua Achebe ${ }^{1}$

Does 1999 represent a break with the Nigerian political past, the advent of democ-

${ }^{1}$ Achebe Chinua. The Trouble with Nigeria. Enugu: Fourth Dimension Publishing, 1983. 
racy in what had been a long-term military dictatorship? In the following macroanalysis, we will hypothesize that there has been a great deal of continuity between some of the presidential periods in the pre-1999 and the post-1999 eras, and that the country pioneered a distinctive African variant of neo-liberal military-directed populism in the pre-1999 period that survived largely, but not completely, intact after 1999. In the latter period it seems to have been directed, we hypothesize, by two of the more egregious pre-1999 neo-liberal military populists, following a neo-liberal populist agenda, and it is this factor more than any other that may explain why it is that Nigeria's post 1999 'democracy' has been so widely criticised as largely undemocratic (Adebanwi and Obadare, 2011: 323).

This article, therefore, examines a conceptual issue in the study of politics which has, over the decades, attracted numerous scholarly writings especially since the 'third wave' of democratization swept across much of Eastern Europe, Africa and some areas of Asia (Huntington, 1991). It deals with what constitutes democracy, what distinguishes democracy from confusingly similar phenomena such as populism, and also how very different regimes might be classified and distinguished from one another based upon these similar criteria. Specifically, in the case of Nigeria, there have been numerous studies that have used various conceptual definitions, classifications and methodological tools to measure types of regime classifications in attempts to interpret the country since its return to civilian rule in 1999 (Diamond, 2002). None of these studies have in our view fully assessed the current civilianisation process in the context of the distinctly military-orientated populist rhetoric that has been used by two former military dictators who have subsequently become presidents and consolidated their political bases, Olusegun Obasanjo (1999-2007) and Muhammadu Buhari (2015-).

The purpose of this article, then, is to contribute to these existing studies of Nigeria by examining whether the last presidential election that brought into office by popular vote a retired military dictator, Muhammadu Buhari, was a victory for democracy, or what this article labels as neo-liberal military-directed populism in Nigeria. It should be emphasised, however, that neo-liberalism is, of course, fundamentally at odds with most populist appeals, who are often more protectionist in economic policies, and yet neo-liberal populism has come to dominate Latin American and European politics in the contemporary setting. Central to neo-liberal populism in the contemporary setting is the reliance on the 'people' for legitimacy as supposed to democratically elected representatives. Earlier analyses of African politics had always characterised that continent's populism as socialist, or social-democratic. These analyses seem to have missed the distinction, so clearly put by Naomi Chazan and others, between 'high politics' and 'deep politics', however. The socialist and democratic socialist populism of Africa in the 1960s and early 1970s, put simply, missed most Africans, few of whom were aware even of the existence of a national state house. Nigeria does have a long history in West Africa in brief periods of what can 
charitably be called quasi-democratization, followed by lengthy periods of military authoritarianism. In this sense, the Nigerians have perhaps come closer to Latin American political patterns than have their West African neighbours. Nevertheless, this most populous of African nations has set political trends that have been influential, indeed pioneering, in the region/Africa. These trends are all too often disregarded by academic analysis at the time, however. In 1968, when Ali Mazrui and G. F. Engholm (1968) discussed the new 'intellectual populism' of Africa, for example, their understanding of African populism completely missed the emerging neo-liberal military Nigerian pattern in defining the new populism as the intellectual overcoming of ethnic divisions through the new socialism of leaders like Kwame Nkrumah and Leopold Senghor, a pattern that soon folded and, in any event, as noted above, barely reached most of the new citizens. When Henry Bienen discussed populist military regimes in West Africa in 1985, he spent more space on Tanzania, an East African country with little military influence, than he did on Nigeria (Bienen, 1985). ${ }^{2}$ It is true that populism is a very slippery term, one that often eludes objective definition. It sometimes appears to share affinities with ideological movements such as socialism, liberalism and nationalism but is however, different. As Margaret Canovan (2005) notes,

... all these 'isms' range over widely varied phenomena, each gains a degree of coherence from a continuous history, willingness on the part of most adherents to identify themselves by the name, distinctive principles and policies. Populism does not fit this pattern [as] there is no acknowledged common history, ideology, programme or social base, and the term is usually applied to movements from outside, often as a term of abuse (Canovan, 2005, p. 79).

Populism, therefore, often strives in societies where there is a weakening of traditional party structures, and/or deep penetration of mass media in its diverse forms. This provides an avenue for a potential political candidate to appeal directly to the electorate while bypassing the traditional political party structures and the ideological commitments they embody. The campaign discourse mainly centred on being the 'outsider' or 'anti-establishment' that promises to take back power from the 'establishment' and give it back to the people.

Since entering into a formal democratisation process in 1999, there have been numerous populist rhetoric used by 'civilian-led' governments has they have attempted with limited success to deal with internal security threats, but also seemed to have used them to build broad-based national support. The first post-1999 'civil-

\footnotetext{
${ }^{2}$ Nevertheless, he did devote three sentences to Nigeria, and managed to mention the Buhari coup, one of the early salvos in military populism in Nigeria: 'The Nigerian coup on 31 December 1983 was led by senior officers. But if the Buhari regime should be discredited, splits will widen in the armed forces and pressures from below will increase. Still, Nigeria remains a country with a middle class that is relatively stable by African standards' (375).
} 
ian' president, retired General Olusegun Obasanjo (1999-2007), a Yoruba, had served between 1976 and 1979 as the military dictator cum President of Nigeria, and as dictator established a democratic, or at least quasi-democratic, constitution, fought corruption (a central populist concern), and eventually handed power over to an elected civilian in 1979, Alhaji Shehu Shagari, thus beginning the short-lived Second Republic. His populist rhetoric and foci, and particularly his firm opposition to the corruption of elites, were central to his post-1999 eight-year civilian and democratically elected presidency. The current elected president, Muhhamadu Buhari (2015- ), a retired Major General who seized power in a coup d'état in 1983, had ended Shagari's presidency and the Second Republic as a military dictator, and was himself deposed by his colleagues in 1985 after attempts to build a popular base by publicising his fight against elite corruption and opposition to part of the IMF loan conditionality, including currency devaluation. As a civilian and elected president he has likewise adopted a distinctly military-orientated populist rhetoric.

The two 'purely civilian' presidents sandwiched between these former military dictators, Alhaji Umaru Yar'Adua (2007-2010) and Goodluck Jonathan (2010-2015), were generally seen to be beholden to their populist military predecessor, and a founding member of their political party, (PDP) Olusegun Obasanjo. Yar'Adua, who died in office in 2010, had the support of Obasanjo, primarily due to his perceived corruptionfree record as a state governor, and because Yar'Adua was a younger brother to Obasanjo's military number two (Major General Shehu Musa Yar'Adua) when the latter was head of state from 1976-1979. Similarly, the then vice-president Goodluck Jonathan also had the support of Obasanjo to succeed Umaru Yar'Adua following his death, even though this was greatly opposed by northern political and military elites. Although both the Yar'Adua and Jonathan presidencies greatly encouraged neoliberal and populist stands on a range of issues, they tended to be assessed as having been less supportive of the neo-liberal military-directed populism that has dominated the civilianisation process in Nigeria since 1999.

The presidencies of Obasanjo and Buhari, and their separate struggles with what we have chosen to call the neo-liberal military-directed populist dilemma, adoption of an anti-establishment and anti-corruption rhetoric while embracing the international and national financial establishment's globalisation prescriptions has been far more typical of Latin American countries than it has of African countries, at least thus far. ${ }^{3}$ The anti-establishment stance in Nigeria, coming as it does from former military dictators and their close supporters, would seem to be ultimately at odds with the tenets of neo-liberalism, however.

\footnotetext{
${ }^{3}$ Former President Carlos Andres Pérez of Venezuela, is a striking case, among many, of this Latin American tendency. His neo-liberal populism resulted in attempts at his overthrow by the military (including one by later leftist president, Col. Hugo Chávez), and his later impeachment for corruption after national outrage following his adoption of IMF mandated wage and price stabilization policies.
} 


\section{ON NEO-LIBERAL POPULISM AND ITS AFRICAN VARIANTS}

Democratising systems are often seen to be very undemocratic during the adaptive democratising stage, ${ }^{4}$ and thus vulnerable to the debilitating influences of demagoguery and populism. ${ }^{5}$ That latter condition is notoriously difficult to define, however, although most observers agree that populism is used primarily as a pejorative term, one that describes a system of which we do not approve, albeit one that invariably holds to the principles of the sovereignty of 'the people', and the natural enmity of 'the elites', however ambiguously these terms are defined (McGuigan, 1992). Canovan argues that recent populist movements stress a 'natural' opposition between 'the people' and their elected representatives. ${ }^{6}$ Ostensibly, then, elected representatives rapidly become 'insiders', or 'elites', and cannot be trusted, whereas the populist president remains transparent and visible. Albertazzi and McDonnell offer a slightly tongue-in-cheek definition that captures some of the spirit and discourse of populism as

an ideology which pits a virtuous and homogeneous people against a set of elites and dangerous 'others' who are together depicted as depriving (or attempting to deprive) the sovereign people of their rights, values, prosperity, identity and voice (Albertazzi; McDonnel, 2008, p. 3).

While it is difficult to identify in any specific instance a clear, populist 'ideology' to which Albertazzi and McDonnel refer, ${ }^{7}$ Howarth clarifies that there are three defining features of populism: appeals to 'the people' as both a political identity and a fundamental recruitment tactic; the creation of a barrier between the underdogs and the establishment (read: 'enemy'), or the power elite; and the creation of effects that define 'the people' (Howarth, 2005, p. 204).

Central to populism is the ambiguous role of the leader, as a charismatic driver of the populist agenda. The populist leader is an agent who embraces symbolic and cultural 'markers', valued elements of popular culture, ${ }^{8}$ that are considered inferior by the dominant elites, and thereby brings dignity to his or her followers, common peo-

\footnotetext{
${ }^{4}$ Samuel P. Huntington's classic argument in his 1968 book, Political Order in Changing Societies, that 'political decay' was a necessary prerequisite of institution building and hence part of democratization, has been roundly disputed by a range of critics, although perhaps most eloquently by Schmitter, P. C. and Karl Lynn, T. 1991. What Democracy Is...and Is Not. Journal of Democracy, 2, 75-88. 1991.

${ }^{5}$ It is often remarked that populism can be democratic, or anti-democratic.

${ }^{6}$ Canovan, Margaret The People. Cambridge, UK: Polity Press, 2005, p. 75.

${ }^{7}$ In their defence, they do mention that populists in Western Europe 'merge their populism with more "established" ideologies, notably liberalism, nationalism, conservatism, federalism and socialism...' (4). Most of these, of course, would not be considered 'ideologies' per se, at least not in the sense that Karl Mannheim used that term.

${ }^{8}$ These can be food items, or cultural practices, or popular art forms, or popular sports, or a range of other popular values.
} 
ple who ostensibly are suffering financially and have felt belittled (Panizza, 2005, p. 26). In so doing, the populist leader reminds the followers of those non-democratic elements that invariably are part of democracy, ${ }^{9}$ and often there by legitimises biases (e.g., racism and other exclusionary practices), the 'dirty secrets' that a truly egalitarian democracy cannot tolerate, but that a populist regime can celebrate, and thereby feel better about itself (Panizza, 2005, p. 27). The populist leader must evince personal qualities that are both ordinary and typical of 'ordinary people'...and also, at the same time, be demonstrative of a special drive and success (Panizza, 2005, p. 21) This, it is thought, is accompanied by a kind of charisma, although as Panizza observes based upon a number of historic populist leaders, that charisma is not necessarily embodied in the populist leader himself. The physical absence of a populist leader may even build his/her 'charisma' more effectively:

The leader's populist enigma is never more evident than when he is physically absent because of exile or other reasons, as has been the case of many populist leaders, including Velasco Ibarra in Ecuador, Haya de la Torre in Peru, and Perón in Argentina. In the leader's absence, his/her return becomes a floating signifier as every utterance, letter or statement becomes open to conflicting interpretations by his followers, while the authority of the absent enunciator cannot be used to fix its 'true meaning' (Panizza, 2005, p. 19-20).

Populism, then, as an apolitical appeal to a set of 'ordinary' values, neither necessarily left nor right of centre, ideological only in a very vague sense ${ }^{10}$ in which, as Albertazzi and McDonnell note, there are four precepts: 'The people are one and inherently "good"....The people are sovereign....The people's culture and way of life are of paramount value....[and] The leader and party/movement are one with the people' (Albertazzi; McDonnel, 2008, p. 6).

In this sense, then, it can be said that there is 'an intimate connection between democracy and populism', and, at the same time, 'also an inherent tension between them ${ }^{11}{ }^{11}$ Of particular relevance is the populist tendency to mistrust elections as incapable of revealing the real will of the people. ${ }^{12}$ This is often coupled with the fundamental belief of populist leaders that the establishment and ruling elite are corrupt

\footnotetext{
${ }^{9}$ Panizza notes that most democracies remain a mixture of egalitarian democratic impulses and nondemocratic feelings in which 'principles of technocratic rationality and guardianship constrain and override the principle of the sovereignty of the people' (31).

${ }^{10}$ Albertazzi and McDonnell note that populists 'merge their populism with more "established" ideologies, notably liberalism, nationalism, conservatism, federalism and socialism' (4), although they add that 'unlike Fascism, for example, populist propaganda insists on the values of equality (among the people) rather than hierarchy and it is the community rather than the state which is said to be paramount' (3).

${ }^{11}$ Or even, as Pasquino argues, a fundamental incompatibility between them. See Pasquino, Gianfranco. Populism and Democracy. In: Albertazzi Danielle and McDonnell Duncan ed. Twenty-first century populism; the spectre of Western European democracy. Hampshire, UK and New York: Palgrave Macmillan, 2008.

12 Ibid.
} 
and manipulative. As an interesting connection with Africa/Nigeria, most military coups have also tend to use corruption and political manipulation by corrupt elites as primary rationales to explain the central question that populism tends to address in all of its iterations, according to Betz and Johnson (2004): 'what went wrong; who is to blame; and what is to be done to reverse the situation'? ${ }^{13}$

In recent years, populism has gravitated in many systems to the right of the political spectrum. Focusing on the 'dirty secrets' that many citizens would rather have restored to some sense of acceptability, if not dignity, such as racism and xenophobia, populism has taken on a decidedly anti-democratic ${ }^{14}$ and facilely demagogic tenor. In Europe, this has meant that most populist movements are stridently neo-liberal and have become focused upon policies that are xenophobic, anti-immigrant, antiMuslim and generally anti-Semitic.

African populism, after the initial elitist, intellectual and socialist phase discussed by Mazrui and Engholm in the 1960s, expressed itself as opposition to conventional political parties, or least to multiple political parties in a system with party competition. This is largely because of two factors: the initial control of political parties by civilian elites after independence; and the rapid movement of political parties after their founding to close identification with specific, often dominant ethnic groups. Single national political movements, such as the Tanganyika African National Union ${ }^{15}$ in Tanzania, on the other hand, were acceptable, even demanded. They would ostensibly take over the system as the single legal 'party', and would thereby dispense with elite manipulation of political processes, as per Schumpeter's characterisation of bourgeois democracy. More recent research of African populism expressing itself in opposition to conventional political parties have further discussed why urban poor vote for opposition parties and the populist strategies used by these political parties to incorporate the urban poor into the mainstream political arena (Resnick, 2014). Other studies have focused on the diverse forms of populism in sub-Saharan Africa by mainly focusing on identity-based, poverty-induced and protest populism (Banywesize, 2013). Emmanuel Banywesize (2013) argues that the first two types ultimately manifests in xenophobia and human rights violations and the justification of dictatorships in numerous sub-Saharan countries.

Central to African populism as ascribed to by military regimes has been an absolute rejection of high-level (elite) corruption while adopting international neo-liberal prescriptions. This has involved what we will refer to as the 'neo-liberal military-

\footnotetext{
${ }^{13}$ As quoted in Albertazzi Danielle and McDonnel Duncan. Ibid.Introduction: The Sceptre and the Spectre.' In: Albertazzi Danielle and McDonnell Duncan ed. See also Betz Hans-Georg; Johnson Carol. Against the Current-Stemming the Tide: The Nostalgic Ideology of the Contemporary Radical Populist Right. Journal of Political Ideologies 9, p. 311-327, 2004.

${ }^{14}$ Particularly if we insist in the definition of democracy on a menu of basic human rights as constituting a critical part of democracy.

${ }^{15}$ Later merged in the late 1970s with Zanzibar's Afro-Shirazi Party into the single legal state party, the Chama cha Mapinduzi, or Party of Revolution.
} 
directed populist dilemma', reliance on 'the people' as a value and the 'establishment' as the enemy, while embracing a largely conservative economic platform that accepts wholesale the neo-liberal demands of the international and national corporations and lending agencies. This stance often requires public rejection of 'structural adjustment policies' advocated by international lending agencies, for example, while quietly supporting them.

\section{NIGERIA'S GRADUAL MOVE TO LIMITED ELECTORAL DEMOCRACY: POPULIST UNITY FROM ETHNIC DIVISION?}

Contrary to expectations by both local and international observers of Nigeria, the 28 March 2015 presidential election was relatively peaceful and was significantly devoid of the political violence that was anticipated prior to the election. For the first time in Nigeria's political history, the country witnessed an incumbent president losing in an election, accepting defeat, and peacefully handing over power to the opposition candidate. Based on the outcome of this election, some political analyst have argued that perhaps Nigeria had come of age in the democratisation process, and could be categorised as having at least a limited form of democracy which, as Andreas Schedler (2006) argues, is a system where elections are free and fair, and opposition parties and candidates can freely campaign without any form of political intimidation by the ruling party. Crucially, the difference between electoral democracy and any other quasi-democratic form, such as an electoral authoritarian system, lies in the degree of freedom, fairness, inclusiveness and meaningfulness of elections that are allowed to take place. A closer examination into the last general election reveals that this might be the case in Nigeria, given that there was apparently a move toward a form of electoral democracy after several flawed attempts (1999, 2003, 2007 and, to a degree, 2011). Despite this, the election also probably highlighted more dangerous trends than in previous elections, that is, the ethnic patterns that seem to have characterised voting.

Since the formal transition of Nigeria from a military authoritarian system to that of civilian rule in 1999, it has been apparently difficult for scholars to characterise the civilianisation process the country has undergone. Part of the reason for this is perhaps the manner in which Nigeria transitioned into a formal democratic system, what Kayode Fayemi described as a 'vague' transition process, a process whereby the predominately Hausa-Fulani military elite, who at that time were keen on protecting its vested interests in the polity, ensured that a retired military general and former military head of state, Olusegun Obasanjo, became president at the end of formal military rule (Fayemi, 1999). To further complicate matters, the leadership style of Obasanjo had significant military elements that were comparable to that of military rule. It constituted a civilian system in which, as Cyril Obi notes, was "a political transition without a democratic transformation" (Obi, 2011, p. 367). That it was also de- 
cidedly populist underscores the extent to which at least some of the earlier military dictatorships were genuinely populist, and decidedly African populist, regimes well before the advent of electoral democracy in Nigeria.

A number of labels have been applied to define Nigeria's Fourth Republic, including pseudo-democratic, garrison, hybrid, militarised, electoral authoritarianism, electoralism, illiberal, and ambiguous, among others (Agbaje; Adejumobi, 2006). It should be noted, however, that even though some scholars are unclear as to why a given label is applied to Nigeria, others go into great detail in justifying their classification (Diamond, 2002). Overall, the studies on democratization in Nigeria over the last decade or so have presented this period as less than democratic although the country typically holds elections that are, at least on paper, multiparty and competitive.

Minus the challenges of providing adequate security in the country which have significantly increased in post-military Nigeria including the rise since 1999 of violent ethnic and religiously-inspired militias, it is important to note that the persistence of electoral irregularities that have marked numerous post-1999 elections in Nigeria suggests that there are challenges to the deepening of democratic principles in the country, especially in major political contests at the federal level. It is therefore, perhaps unsurprising that a significantly number of electoral outcomes have resulted in violence. For example, it has been estimated that in first six years of the civilisation process in Nigeria (1999 to 2006), more than 11,000 Nigerians lost their lives in electoral violence (Ewi, 2015, p. 217). Considering that Nigeria's political arrangement is ostensibly that of a competitive multi-party system, it might have been expected that this pluralistic arrangement, one that guarantees a diversity of choices in elections, would minimise at least to some extent cases of electoral violence. However, an examination of the political parties in Nigeria, (approximately 63 in number) shows that a majority of them are financially insolvent and ideologically nondescript. A significant number of these parties are inactive, effectively cease to exist in any meaningful sense immediately after elections, and mainly exist to collect grants from the Independent National Electoral Commission (INEC). They also serve as a form of 'fall back mechanism' for elite members of the ruling party when and if they have disagreements with their own ruling party (Obi, 2011).

The most important phenomenon that best characterises the perversion of the electoral system and party process in Nigeria is what is termed the 'political godfather' phenomenon within the political party processes. This phenomenon, which is significantly pronounced within the ruling political parties, consist of political "individuals [who] possess considerable means to unilaterally determine who gets a party's ticket to run for an election and who wins in the electoral contest" (Obi, 2011, p. 367). A successful political godfather is therefore, a person or group of persons who have financial resources, and the ability to manipulate the grassroots and/or political constituencies, to determine electoral victories. In a scenario where the 'anointed 
godson/person' is facing near electoral defeat, the political godfather is able to use violence and/or corruption to manipulate the system to their advantage.

The godfather phenomenon in Nigeria's political party machinery has become a significant contributor to numerous anti-democratic practices that have occurred in the democratisation process since 1999 (Albert, 2005). These 'political godfathers' promote a closed system of political recruitment and selection process. Aspiring candidates or elected 'godsons' must consult with the godfather on all major political issues, and failure to do so can lead to violence. An example of this occurred in Anambra state between 2003 to 2006 period. The then-governor of the state, Chris Ngige, fell out of favour with his political godfather, Chris Uba, and the crises that ensued were never resolved. Eventually Ngige was expelled from office in 2006 when an election tribunal nullified his 2003 election ex post facto, a ruling that was upheld by a Federal Court of Appeals (Newsday, 2015).

It is within this political context that anti-democratic elements have undermined popular participation. When Nigeria went to the polls on 28 March 2015, local and international observers were concerned that the election might be among the bloodiest in Nigeria's political history. Some commentators even suggested that the election might threaten the very existence of the Nigerian state. ${ }^{16}$ There was a high level of insecurity in the country at the time, especially in the northeast, where Boko Haram had occupied a large territory, claiming it as part of the larger Islamic State of Iraq and the Levant (ISIL). In addition, the Jonathan government also had to confront a sluggish economy because of the falling prices of crude oil, a high unemployment rate, and a severe fuel scarcity, all just prior to the election. The feared violence did not take place, however, and the first peaceful and constitutional handover of power from one party to another in Nigerian political history took place.

The election of 28 March therefore was a success, exemplifying the Nigerian electoral democracy under extreme stress, with a weary electorate dominated by a populist party for 16 years, tired of broken promises by that party, and yet still very vulnerable to populist rhetoric. Anti-corruption, the populist icon, was front and centre, with media reports that alleged that some of Jonathan's key ministers were greatly misappropriating public funds for private gains. Additionally, personal security, and the rise of a Muslim guerrilla organisation, Boko Haram, against which the military seemed powerless, added a component of fear to the populist rhetoric of the main opposition party, the All Progressives Congress (APC), and its campaign slogan, 'change'. The APC had been formed in 2013 with the merging of the three main opposition parties - the Action Congress of Nigeria (ACN), the Congress for Progressive Change (CPC), All Nigeria Peoples Party (ANPP), and a faction of the All Progressives Grand Alliance (APGA).

Perhaps the key to the peaceful transition was, in fact, the question of security. To

\footnotetext{
${ }^{16}$ For more on the last presidential elections see Ewi Martin. Was the Nigerian 2015 presidential election a victory for boko haram or for democracy? African Security Review 24, p. 207-231, 2015.
} 
solidify their opposition credentials, the APC nominated another former military ruler, Major General Mohammadu Buhari, who had previously sought the elected position of president on three different occasions, but had failed in the past as the alternative to Jonathan's PDP. Buhari was seen as an incorruptible individual whose previous military credentials suggested that he could tackle the many socio-economic challenges confronting Nigeria as an 'outsider', just as he had attempted to do as military head of state between 1983 and 1985, while addressing the fundamental question of personal security.

The last general election in Nigeria, therefore, seems at first glance at least, to have been a victory for electoral democracy. The ability of Nigeria to conduct a relatively credible election that unseated an incumbent president and at the same time did not descend into extreme post-electoral violence, represented a formidable victory for electoral democracy. It also appears, however, to have represented a victory for neo-liberal populism, given the platform of the Buhari candidacy and his early policies. While it remains too early to know whether subsequent elections, especially at the lower levels (state and local governments), will become more credible, less vulnerable to populist rhetoric and policies, and less devoid of post-electoral violence, these outcomes seem unlikely.

We can focus on the praise from both local and international observers over the conduct of the election and the manner in which Goodluck Jonathan called Mohammadu Buhari on phone even before the final electoral results were declared by INEC to concede defeat. Nevertheless, it would be mistaken to ignore the deep ethno-religious divide that continue to characterise the system. Significant numbers of Igbos and ethnic groups from the Niger Delta (were Jonathan comes from) voted for the incumbent president, while the Yoruba and Hausa-Fulani tended to vote for Buhari (Owen; Usman, 2015). The bitter ethnic divide between the Igbos and the Yoruba, which persisted after the end of the Biafra war, still affects these two major ethnic groups. Although the last general election has been praised globally, and seems to highlight a degree of maturity in the democratising process in Nigeria, it appears it has continued the populist patterns of post-1999 Nigeria, and has left unresolved key elements of ethnic voting that calls into question the basis of national unity that is so vital to continuing democratization in Nigeria.

\section{THE EMERGENCE OF NEO-LIBERAL MILITARY-DIRECTED POPULISM IN NIGERIA}

The relative success of the 2015 presidential election raises a key question relating to whether the victory of a former military dictator is a victory for democracy in Nigeria, or rather what this article hypothesises is the emergence of neo-liberal militarydirected populism. As earlier noted, populism, even though not extensively discussed in Nigerian literature, is not new to the country. It has its roots in neo-liberal militarydirected populism that traces back to a period in the political history of the country 
when the military justified its intervention in politics as the necessary result of the failure of civilian political elites and rampant elite political corruption. The military intervened at that juncture as a 'corrective regime', ostensibly to eradicate political corruption and encourage the adoption of neo-liberal economic policies, although at the inception of the regime, they appear to be protectionists in terms of economic policies.

It must be emphasised, however, that neo-liberal military-directed populism in $\mathrm{Ni}$ geria should be distinguished from other populist strategies that may have been employed by numerous political elites (both federal and local) since democratization in 1999. It is also different in a general context from political and/or social movements that appeal for popular support on different kinds of policies such as, empowering women, gay rights, allowing Syrian refugees into Europe etc. Neo-liberal militarydirected populism in Nigeria can be labelled as a synonym of demagogy or political opportunism that have been used effectively by two former military dictators (Olusegun Obasanjo and Mohammadu Buhari), who have subsequently become presidents post-1999 to legitimise their political parties' electoral victories and to consolidate their political gains. In and out of political office, these two ex-military generals have presented themselves as the 'outsider' and attack the corrupt 'establishment'/ 'professional politicians' or 'ruling elites' for not taking a hard stance on core issues that will ameliorate the sufferings of the large poor population in Nigeria. The pattern in which neo-liberal military-directed populism has apparently manifested itself in post-military Nigeria has taken three forms: first, in an emphasis on fighting elite corruption; second, in an emphasis on national security in an era of insecurity; and, lastly, at first glance appears to be economic protectionist policies, and yet adopt several international neo-liberal prescriptions of Bretton-Woods institutions such as the International Monetary Fund (IMF).

First, corruption in all its ramifications has been described as a malicious cancer in Nigeria and the country has, indeed, ranked among the most corrupt nations in world according to respected international reports, such as Transparency International's (TI) Corruption Perceptions Index (CPI). Under the period of military rule in Nigeria, this corruption rhetoric was used by virtually all military coup plotters to justify their takeover of government. Also, their takeover speeches or initial press meetings all had a similar pattern of emphasising this corruption rhetoric and ranged from General Murtala Mohammed 1975 takeover speech were he stated,

Fellow Nigerians, events of the past few years have indicated that despite our great human and material resources, the government has not been able to fulfil the legitimate expectation of our people; Nigeria has been left to drift...(Daily Times, 1975, p. 3)

To that of Major General Muhammadu Buhari, who in his first press conference in 1984 after the 31 December 1983 military takeover outlined the regime ten point 
agenda that included, "clean[ing] the society of the cankerworm of pervasive corruption" (Daily Times, 1984, p. 1). And General Sani Abacha who affirmed the inauguration of the Provisional Ruling Council (PRC) on 24 November 1993 that his government will "mobilise all resources at its disposal to fight the menace of corruption, armed banditry and drug trafficking" (Abdulsalami, 1993, p. 26). Under the current civilianisation process, this corruption rhetoric has continued. It is, therefore, unsurprising that upon assumption of office on 29 May 1999, Olusegun Obasanjo stated that there would be 'no sacred cows' during his administration. In his inaugural speech, Obasanjo noted that no society can achieve anything close to its full potential if it allows corruption to become the 'full-blown cancer' that it had become in Nigeria. He went on to note that corruption was "the greatest single bane of [Nigeria's] society today [and would] be tackled head-on at all levels" (Nigeria World, 1999).

As an indication of its determination to fight corruption, the government instituted the Christopher Kolade Panel to review all previous appointments, contracts, licenses, approvals and awards made by governments' after 1966, when the military had first directly intervened in politics. To legalise the anti-corruption campaign, an anticorruption bill was submitted to the National Assembly; this later became law, on 13 June 2000. It prohibits most forms of corruption and prescribes punishments for corrupt practices and other related offences. It also defines corruption that is punishable by law. The government established two anti-corruption agencies, the Independent Corrupt Practices and other Related Offences Commission (ICPC), and the Economic and Financial Crimes Commission (EFCC). The ICPC is empowered by law to investigate, try and assign punishments, while the EFCC is mandated to investigate and prosecute financial crimes such as advance fee fraud ( 419 fraud) and cases of money laundering.

Throughout the Obasanjo administration, there were numerous media reports that the government's anti-corruption fight was yielding results. During the first phase of that presidency, politicians and top-level bureaucrats were reported to have refunded to the government money that was reported to have been taken through corrupt practices. Western governments and big transnational banks also aided the government in recovering some of the resources reportedly taken by former military ruler General Sani Abacha. ${ }^{17}$ Under the current government of Muhammadu Buhari, there are significant similarities between the Obasanjo populist anti-establishment positions in office, especially in the area of fighting corruption, and those of the Buhari government. Since Buhari's assumption of office, numerous financial investigations into alleged corruption of the government of Goodluck Jonathan have been initiated (Daniel; Nnochiri, 2015). Prominent individuals in the past government, such as the former national security adviser retired Colonel Sambo Dasuki, then minister of

\footnotetext{
${ }^{17}$ For more on the initial efforts made by the Olusegun Obasanjo government to trace the money stolen by General Sani Abacha see Guardian Newspaper. Tracking the billions. The guardian newspaper (Nigeria). p. 8-9, 2000.
} 
petroleum and finance, Allison Madueke and Ngozi Okonjo-Iweala, and high ranking retired and serving military officers, have been accused by the current government of misappropriating public funds in their given political portfolios (Premium Times, 2015).

Second, just as in military rule in Nigeria were another key rhetoric used by the military elites to justify their intervention in politics related to maintaining law and order, and guaranteeing the security of life and property, the maintenance of national security has been an important component of the rhetoric used under the post1999 civilian governments, especially given the protracted state of insecurity in the country. The most notable threat at present is that of Boko Haram that mainly operates in the north-eastern part of the country.

During the last presidential campaign, the APC effectively used this rhetoric of national security in their party campaigns across the country to justify Muhammadu Buhari's credentials for president over than of Goodluck Jonathan, and they also emphasised the need to elect an individual with military background given the dire state of insecurity in the country. In one of such campaigns held in Lagos, Ahmed Bola Tinubu, a key leader of the APC, although not historically accurate in the statements made during this campaign rally, stated that:

I prayed that Nigeria would get better and we would not need a man like him [Buhari]. But today, we are in great crises; we face a lot of challenges. When South Africa was in a great dilemma and was about to disintegrate, they called Nelson Mandela of 74 years old. He used his wisdom to save his country. When the United States was in economic depression they called 73 years old Ronald Reagan because he was frugal and incorruptible... when America was faced with depression and war, they called a retired General, Dwight Eisenhower, to rescue the country and the country was returned on a path of success. When France was faced with war and economic depression, they called a retired General, Charles De Gaulle; to rescue the country... so what do we need now? Buhari... we are calling you to come and rescue us in Nigeria (Sotubo, 2015).

In addition to the rhetoric of national security and the protection of life and property, the maintenance of national security in the country appears to be interwoven with a deliberate strategy of all four post-1999 presidents in Nigeria to strengthen and re-emphasise the secular nature of the Nigerian state, especially as it relates to guaranteeing individual rights of freedom of religion. This has, however, represented a separate set of challenges. For example, at the end of 2001, twelve majority Muslim states in Nigeria instituted the application of sharia (Islamic law) even though this caused numerous controversies regarding the legality of such action. Some political analysts went so far as to argue that the implementation of sharia by these states violated the 1999 Constitution. The response of President Obasanjo, a Christian from the South, to address these concerns, was notably indecisive, moreover. He said that 
the situation represented a kind of 'political sharia', rather than a 'real sharia', and that it would 'soon fizzle out' (Nmehielle, 2004, p. 754). The perceived passivity of Obasanjo and subsequent governments to sensitive religious issues, especially in a 'religiously charged' country like Nigeria, appears to have added to a climate of insecurity in the country.

That is why it seems problematic for previous and the current government to address the threats posed by Boko Haram. For example, even though it is known that in recent times Boko Haram has been using young girls wearing hijabs/burqa as suicide bombers, the government seems unable to take a more drastic approach that might include the outright banning of hijabs/burqa worn by women in public places in communities greatly affected by Boko Haram. Such actions would only lead to more radicalisation and thus be counter-productive (Economist, 2016).

Lastly, all four of the post-1999 Nigerian leaders have overtly embraced and encouraged numerous neo-liberal economic policies, as prescribed by Bretton-Woods institutions such as the World Bank and the International Monetary Fund (IMF). Historically, the World Bank and the IMF were initially created immediately after the Second World War, in 1945, to stabilise the global economic system and prevent the return to the 1930 s economic nationalism that the great powers at that time had implemented in response to the great depression. The roles these financial institutions play in the global economic system include encouraging free trade, advising the monetary policies of states, and providing loans with conditionalities to those countries that are experiencing balance-of-payments difficulties. Such conditionalities usually include exchange-rate adjustments (devaluation of currency) and the total removal of subsidies and tariffs that restrict imports of goods at full international prices, etc. (Gilpin, 1987).

However, Nigeria's first formal request for financial assistance (loan) with its conditionalities from the IMF did not occur until the mid-1980s. The Bretton-Woods inspired Structural Adjustment Programme 'SAP' was introduced to Nigeria in 1986 under the regime of General Ibrahim Babangida (1985-1993) as a lasting solution to the country's frequent and continuous economic cycles of prosperity and depression, thought to be based upon its over-reliance on a single natural resource (crude oil) as it major source of foreign exchange. The measures recommended as part of the loan conditions meant that Nigeria had to undergo a major devaluation of its currency, privatise public enterprises, deregulate the domestic market, liberalise foreign trade and credit, and put restraints on its money supply. Unsurprisingly, the implementations of the IMF loan conditions have had a profound negative effect on the Nigerian economy. Under Babangida, the per capita income of US\$778 in 1985, declined to US\$175 in 1988 and further dropped to US\$108 in 1989 (Osaghae, 1998: 204). Since that period, there has been a drastic and continuous visible decline in the maintenance and construction of the basic social infrastructure. The quality of public education has fallen significantly, there is a continuous massive brain drain, and access to 
basic government services such as health care has become prohibitively expensive for many and unreliable for the rest. This has directly fed into the neo-liberal militarydirected populist rhetoric because a significant number of Nigeria's large poor population are vulnerable to rhetoric that promises to provide or implement policies that would address their needs, for example, provision of free and qualitative health care, free education up to the tertiary level and full employment etc.

All four post-1999 leaders in Nigeria have greatly encouraged numerous neoliberal populist economic policies. Under Umaru Musa Yar'Adua government (20072010), its economic policy to ameliorate the sufferings of the large poor population of the country was called the 'seven-point agenda'. These seven areas the government reasoned were at the core of revamping Nigeria's socio-economic development. The seven areas were power and energy; infrastructure; food security; wealth creation; transport sector; land reforms; security; and, education. Similarly, under Goodluck Jonathan (2010-2015), the government created another economic program called the 'transformation agenda'. Just as the previous economic policy of Umaru Yar' Adua, this program was meant to address the inability of Nigeria to actually achieve its full economic potentials and also ameliorate the sufferings of the populace. The transformation agenda program, however, had a much wider scope than the previous economic policy of Yar'Adua as it was designed to revamp the entire economic and bureaucratic sectors of Nigeria at the same time. As a result, the program was meant to transform the transport sector, energy and petroleum, finance and banking, agriculture, create jobs, and strengthen the capital market etc.

In terms of neo-liberal military-directed populism that has been used by Olusegun Obasanjo (1999-2007) and Mohammadu Buhari (2015-), the economic policy used by these two former military generals before assumption into office and/or during the earlier stages of their presidencies appear to have a semblance with economic protectionism especially in the area of protecting local industries, currency control/fixed exchange rate mechanism and retaining petroleum subsidy. Under Obasanjo's government, there were policies that banned certain products from being imported into the country. For example, the banning of foreign firms importing cement unless those firms had plans to set-up plants in Nigeria. There were also bans on poultry products, furniture, bottled water and fruit juice etc. The rationale for this policy was for the protecting of certain local industries and at the same time boost Nigeria's manufacturing capability significantly. However, Obasanjo's economic protectionist policies were contradicted by other economic policies implemented by the same government. For example, the government actively encouraged several neo-liberal economic policies such as, allowing significant private sector participation in the economic sector and implemented numerous structural reforms that ranged from privatisation of some state-owned public enterprises, the liquidation of others (Nigeria Airways), the deregulation of the petroleum sector, reforming the civil service, banking sector, and the liberalization of certain trade policies etc. (The Economist, 2014). In addition, 
the government created the National Economic Empowerment and Development Strategy (NEEDS). In sum, the NEEDS program significantly emphasised the role private sector partnership can play in the economic development of Nigeria. This the government felt was achievable based on the belief that the private sector is an important driver to wealth creation and poverty reduction in any society (OkonjoIweala; Osafo-Kwaako, 2007).

A similar trend has continued under Buhari's government. However, unlike his predecessors, the current president is yet to come up with a 'fancy' name for his economic program although during his electoral campaign he mentioned several economic areas that his government would immediately address if elected. These areas, however, do not differ significantly from the other economic programs of the previous governments' post-1999. What stood out in the APC campaign program was the promise of paying unemployed Nigerian youths a monthly stipend of $\$ 5,000$. However, in the first half of 2016, Buhari backtracked on this party promise and stated that his government had a different priority at this moment which included empowering unemployed youths to get back into the workforce (Nwabughiogu, 2015). Also, just as in Obasanjo's presidency, Buhari's economic policies have moved from aspects that have economic protectionist policies to the adoption of more neo-liberal economic policies. For example, the government initially introduced a fixed exchange policy/currency control as a means of saving up Nigeria's foreign reserves due to the current low price of crude oil in the international market that have significant reduced Nigeria major source of foreign exchange earnings. Also, as part of Buhari's electoral campaign pledge, the government affirmed that the functional capability of the state-run Nigeria National Petroleum Corporation (NNPC) will be strengthen significantly. This basically meant functional oil refineries working at their optimum operational capacity and the non-removal of petroleum subsidy. However, in the second half of 2016, the government backtracked on these campaign promises and basically re-introduced policies that the APC/Buhari had previously heavily criticized the Goodluck Jonathan government of, I mean, petroleum subsidy removal and restoring the ability of market forces to determine the exchange rate (Onu; Wallace, 2016).

\section{CONCLUSION: THE NEO-LIBERAL MILITARY-DIRECTED POPULIST PARADOX IN NIGERIA}

This article hypothesized that there has been a great deal of continuity between some of the presidential periods in the pre-1999 and post-1999 eras, and that Nigeria appears to have pioneered a distinctive African variant of neo-liberal militarydirected populism in the pre-1999 period that survived largely, but not completely, intact after 1999. This also seems to explain why numerous scholarly writings on $\mathrm{Ni}$ geria post-1999 has been widely criticised as largely undemocratic. This conclusion among scholars on Nigeria is not surprising considering the various undemocratic ac- 
tivities that recur in the polity and has been explained in this article. However, even though it can be argued that Nigeria has made significant progress in its democratisation process since its transition from military dictatorship, this article argues that there is a preference for populism over democracy in Nigeria. It should be noted, that populism can exist in democratising systems such as Nigeria, especially when at present there is a general resentment among the populace that their elected representatives are not adequately catering for their needs. As Koen Abts and Stefan Rummens notes,

Populist resentments arise when constitutional democracy is perceived to be out of balance in favour of the constitutional pillar... [and] that elected representatives are out of touch with the popular will generate the feeling that popular sovereignty is undermined (Abts and Rummens, 2007, p. 405424).

It is within these general resentments that has allowed Olusegun Obasanjo and Muhammadu Buhari to capitalise on and continue this neo-liberal military-directed populism, which may have even further prolonged military rule in Nigeria if not for General Sani Abacha who decided to favour a more statist and nationalist economic agenda in power. Abacha decided not to negotiate with the Bretton-Woods institutions and under his rule Nigeria accumulated millions of dollars of debt arrears. Throughout his regime, the country did not solicit any loans from these international financial institutions (Lewis, 1996).

Finally, this article suggests that there seems to be a preference for populism over democracy in Nigeria, although it is somewhat of a paradox. As political events have shown in Nigeria, the anti-establishment neo-liberal military-directed populist rhetoric used mainly by the two presidents who were the foci of this study, appear to have done the opposite of their rhetoric in government. Which is, the failure to significantly implement their populist economic policies in office (elements of economic protectionism), significantly guarantee national security and fight elite corruption. This paradox conclusion on neo-liberal military-directed populism in Nigeria is similar to a recent research conducted by Danielle Resnick (2014), who noted similar trends in some other democratising African countries. However, it should be noted that Resnick central thesis focused entirely on why the urban poor in African democracies tend to vote for oppositions parties and used cases that did not have decades of military rule in the analyses (mostly Zambia and Senegal). This article, however, analysed populism with a case (Nigeria) that historically, had decades of military rule which was essentially, the norm in a majority of African countries for decades. Therefore, more research on populism in an African context needs to go beyond the diverse forms of populism in Africa as analysed by Banywesize (2013) or the populist strategies adopted by some African leaders in office (Makulilo, 2013). More research on populism needs to be conducted on African societies that have had decades of mili- 
tary rule and are now in various phases of democratisation. Whether there is a great deal of continuity between some of their past populist military rulers and their current democratising political elites and the effect it may have on the various phases of Africa democratization.

\section{BIBLIOGRAPHY}

ABDULSALAMI, Isa. Abacha renews hope as PRC members take oath. The guardian newspaper (Nigeria). 1-2, 1993.

ABTS, Koen; RUMMENS, Stefan. Populism versus democracy. Political studies 55, p. 405-424, 2007.

ACHEBE, Chinua. The trouble with Nigeria. Enugu: Fourth Dimension Publishing, 1983 ADEBANWI, Wale; OBADARE, Ebenezer. The abrogation of the electorate: an emergent African phenomenon. Democratization 18, p. 311-335, 2011.

AGBAJE, Adigun; ADEJUMOBI, Said. Do votes count? the travails of electoral politics in Nigeria. Africa development XXXI, p. 25-44, 2006.

ALBERT, Issac Olawale. Explaining 'godfatherism' in Nigerian politics. African sociological review 9, p. 79-105, 2005.

ALBERTAZZI, Danielle; MCDONNELL, Duncan. Introduction: the sceptre and the spectre.' In: ALBERTAZZI, Danielle; MCDONNELL, Duncan ed. Twenty-first century populism; the spectre of Western European democracy. Hampshire, UK and New York: Palgrave Macmillan, 2008.

BANYWESIZE, Emmanuel. The facets and offshoots of populism in Sub-Saharan Africa In: Gherghina Sergiu, Mişcoiu Sergiu and Soare Sorina ed. Contemporary populism: a controversial concept and its diverse forms Newcastle upon Tyne: Cambridge Scholars Publishing, 2013.

BETZ, Hans-Georg; JOHNSON, Carol. Against the Current-Stemming the tide: the nostalgic ideology of the contemporary radical populist right. Journal of political ideologies 9, p. 311-327, 2004.

BIENEN, Henry. Populist military regimes in West Africa. Armed forces and society 11, p. 357-377, 1985.

CANOVAN, Margaret. The people. Cambridge, UK: Polity Press, 2005.

DAILY TIMES. Murtala Mohammed Speech on Takeover. Daily times (Nigeria). p. 3, 1975.

DAILY TIMES. The Daily times (Nigeria). p. 1, 1984.

DANIEL, Soni; NNOCHIRI, Ikechukwu. Dasuki, dokpesi, others charged with money laundering. Vanguard newspapers (Nigeria), 2015.

DIAMOND, Larry. Thinking about hybrid regimes. Journal of Democracy 13, p. 21-35, 2002.

THE ECONOMIST. The veil in West Africa, banning the burqa. The Economist. p. 35-37, 2016. 
EWI, Martin. Was the Nigerian 2015 presidential election a victory for boko haram or for democracy? African Security Review 24, p. 207-231, 2015.

FAYEMI, Kayode. (1999) Military Hegemony and the Transition Program. A Journal of Opinion 27: 69-72.

GILPIN, Robert. The political economy of international relations. Princeton: Princeton University Press, 1987.

GUARDIAN NEWSPAPER. Tracking the billions. The guardian newspaper (Nigeria). p. 8-9, 2000.

HOWARTH, David. Populism or popular democracy? The UDF, workerism and the struggle for radical democracy in South Africa. In: Panizza Francisco ed. Populism and the mirror of democracy. London and New York: Verso, 2005.

HUNTINGTON, Samuel. Political order in changing societies. New Haven: Yale University Press, 1968.

HUNTINGTON, Samuel. The third wave, democratization in the late twentieth century. Norman, Okla: University of Oklahoma Press, 1991.

LEWIS, Peter. From prebendalism to predation: the political economy of decline in Nigeria. The Journal of Modern African Studies 34, p. 79-103, 1996.

MAKULILO, Alexander. Populism and democracy in Africa. In: Gherghina Sergiu, Mişcoiu Sergiu and Soare Sorina ed. Contemporary populism: a controversial concept and its diverse forms Newcastle upon Tyne: Cambridge Scholars Publishing, 2013.

MAZRUI, Ali; ENGHOLM, GF. Rousseau and the intellectualized populism in Africa. The Review of Politics 30, p. 19-32, 1968.

MCGUIGAN, Jim. Cultural populism London and New York: Routledge, 1992.

NEWSDAY. 10 things to know about chris ngige. Available at: http://newsday.com.ng/ 10-things-to-know-about-chris-ngige/, 2015.

NIGERIA WORLD. Inaugural speech by his excellency, president olusegun obasanjo following his swearing-in as president of the Federal Republic of Nigeria on May 29, 1999

Available at: http://nigeriaworld.com/feature/speech/inaugural.html, 1999.

NMEHIELLE, Vincent Obisienunwo Orlu. (2004) Sharia law in the northern states of Nigeria: to implement or not to implement, the constitutionality is the question. Human Rights Quarterly 26, p. 730-759, 2004.

NWABUGHIOGU, Levinus. Payment of $\$ 5,000$ to unemployed youths begins next year - F G. Vanguard Newspaper (Nigeria), 2015.

$\mathrm{OBI}$, Cyril. Taking back our democracy? the trials and travails of Nigerian elections since 1999. Democratization 18, p. 366-387, 2011.

OKONJO-IWEALA, Ngozi; OSAFO-KWAAKO, Philip. Nigeria's economic reforms: progress and challenges. Washington DC: The Brookings Institution, 2007.

ONU, Emele; WALLACE, Paul. In retreat for buhari, Nigeria prepares to let naira weaken. Available at: http://www.bloomberg.com/news/articles/2016-05-24/nigeria- 
central-bank-to-allow-greater-flexibility-in-fx-market, 2016.

OSAGHAE, Eghosa. Crippled giant: Nigeria since independence. London: Hurst and Company, 1998.

OWEN, Olly; USMAN, Zainab. Why goodluck jonathan lost the Nigerian presidential election of 2015. African Affairs p. 1-17, 2015.

PANIZZA, Francisco. Introduction: populism and the mirror of democracy. In: Panizza Francisco ed. Populism and the mirror of democracy. London and New York: Verso, 2005.

PASQUINO, Gianfranco. Populism and democracy. In: Albertazzi D and McDonnell D ed. Twenty-first century populism; the spectre of Western European democracy. Hampshire, UK and New York: Palgrave Macmillan, 2008.

PREMIUM TIMES. How jonathan, okonjo-iweala illegally diverted $\$ 61.4$ billion abacha loot to NSA, sambo dasuki. Premium Times (Nigeria), 2015

RESNICK, Danielle. Urban poverty and party populism in African democracies. New York: Cambridge University Press, 2014.

SCHEDLER, Andreas, ed. Electoral authoritarianism: the dynamics of unfree competition. Boulder: Lynne Rienner Publishers, 2006.

SOTUBO, Jola. Bola tinubu APC leader says he sacrificed presidential ambition for buhari. Available at: http://pulse.ng/politics/bola-tinubu-apc-leader-says-hesacrificed-presidential-ambition-for-buhari-id3448709.html, 2015.

THE ECONOMIST. Dangote group, building on concrete foundations. The Economist, 2014.

Article received on August 10, 2017

Accepted on August 14, 2017 